\title{
Sedimentological and paleontological analysis of the Lower Jurassic part of the Zatrnik Formation on the Pokljuka plateau, Slovenia
}

\author{
Sedimentološka in paleontološka analiza spodnjejurskega dela \\ Zatrniške formacije na Pokljuki, Slovenija
}

Luka GALE ${ }^{1,2}$, Duje KUKOČ ${ }^{3,4}$, Boštjan ROŽIČ ${ }^{1}$ \& Anja VIDERVOL ${ }^{1,5}$

\begin{abstract}
${ }^{1}$ Department of Geology, University of Ljubljana, Aškerčeva c. 12, SI-1000 Ljubljana, Slovenia; luka.gale@ntf.uni-lj.si
${ }^{2}$ Geological Survey of Slovenia, Dimičeva ul. 14, SI-1000 Ljubljana, Slovenia; luka.gale@geo-zS.si

${ }^{3}$ Ivan Rakovec Institute of Palaeontology, Research Centre of the Slovenian Academy of Sciences and Arts, Novi trg 2, 1000 Ljubljana, Slovenia

${ }^{4}$ Croatian Geological Survey, Sachsova 2, HR-1000 Zagreb, Croatia; dkukoc@hgi-cgs.hr

${ }^{5}$ Prijateljev trg 2, SI-1310 Ribnica; anja.vidervol@gmail.com
\end{abstract}

Prejeto / Received 7. 7. 2021; Sprejeto / Accepted 29. 10. 2021; Objavljeno na spletu / Published online 28. 12.2021

Key words: Lower Jurassic, Bled Basin, Pokljuka Nappe, stratigraphy, foraminifer, Hierlatz facies, Ribnica Breccia, Zajamniki

Ključne besede: spodnja jura, Blejski bazen, Pokljuški pokrov, stratigrafija, foraminifera, hierlaški facies, Ribniška breča, Zajamniki

\begin{abstract}
The uppermost Ladinian to Lower Jurassic Zatrnik Formation is the lithostratigraphic unit of the Mesozoic deeper marine Bled Basin. The uppermost part of the Zatrnik Formation and the transition into the overlying Ribnica Breccia was logged at the Zajamniki mountain pasture on the Pokljuka mountain plateau in the Julian Alps. The lowermost part the section belongs to the "classical" Zatrnik Formation and is dominated by beige micritic limestone and fine-grained calcarenite. Foraminifers Siphovalvulina, ?Everticyclammina, ?Mesoendothyra and ?Pseudopfenderina are present, indicating Early Jurassic age. The beige limestone is followed by light pink limestone of the uppermost Zatrnik Formation. Slumps are common in this interval, and crinoids are abundant. Alongside some species already present in beds lower in the succession, Meandrovoluta asiagoensis Fugagnoli \& Rettori, Trocholina sp., Valvulinidae, small Textulariidae, Lagenida, and small ?Ophthalmidium also occur in this interval. Resedimented limestone predominates through the studied part of the Zatrnik Formation, indicating deposition on the slope or at the foot of the slope of the basin. The switch to crinoid-rich facies within the slumped interval of the Zatrnik Formation may reflect accelerated subsidence of the margins of the Julian Carbonate Platform in the Pliensbachian. The Zatrnik Formation is followed by the formation of the Pliensbachian (?) Ribnica Breccia. Impregnations of ferromanganese oxides, violet colour, and an increase in clay content are characteristic. The foraminiferal assemblage consists of Lenticulina, small elongated Lagenida, and epistominids. Individual beds of the Ribnica Breccia were deposited via debris flows. Enrichments in ferromanganese oxides point to slower sedimentation.
\end{abstract}

\section{Izvleček}

Zgornjeladinijska do spodnjejurska Zatrniška formacija je značilna litostratigrafska enota mezozojskega Blejskega bazena. Zgornji del Zatrniške formacije in prehod v mlajšo Ribniško brečo smo posneli na planini Zajamniki na Pokljuki. Najnižji del posnetega zaporedja pripada "klasičnemu" delu Zatrniške formacije. Najpogostejši litologiji v tem delu sta mikritni apnenec bež barve in drobnozrnat kalkarenit. Določene so bile foraminifere Siphovalvulina, ?Everticyclammina, ?Mesoendothyra in ?Pseudopfenderina, ki dokazujejo zgodnjejursko starost. "Klasičnemu" delu Zatrniške formacije sledi svetlo rožnat apnenec, ki še vedno pripada Zatrniški formaciji. Za ta interval so značilne strukture podvodnega plazenja. Pogosti, v nekaterih plasteh prevladujoči, so delci morskih lilij. Poleg že prej omenjenih rodov foraminifer, so tukaj prisotne še Meandrovoluta asiagoensis Fugagnoli \& Rettori, Trocholina sp., Valvulinidae, drobne Textulariidae, Lagenida, in drobni ?Ophthalmidium. Resedimenti, ki prevladujejo v obeh posnetih delih Zatrniške formacije, kažejo na sedimentacijo na pobočju ali ob vznožju pobočja. Prehod v rožnat apnenec s pogostimi sledovi plazenja in obilico ploščic morskih lilij bi lahko odražal pospešeno pogrezanje robov Julijske karbonatne platforme v pliensbachiju. Zatrniški formaciji sledi formacija pliensbachijske (?) Ribniške breče. Značilne so impregnacije z železovomanganovimi oksidi, vijolična barva kamnine in večja količina glinene primesi. Foraminiferno združbo sestavljajo Lenticulina, drobne razpotegnjene Lagenida in epistominide. Plasti Ribničke breče so bile odložene z drobirskimi tokovi. Obogatitve z železovo-manganovimi oksidi kažejo na počasnejšo sedimentacijo. 


\section{Introduction}

The Middle Triassic regional extension of the continental crust at the western margin of the Neotethys Ocean resulted in the formation of numerous intraplatform basins separated by topographic highs and platforms (Buser, 1989, 1996; Bosellini et al., 2003; Kovács et al., 2011). Although by the early Carnian most of the smaller basins were already filled with sediments of prograding platforms and/or clastic deposits (Bosellini et al., 2003; Breda et al., 2009; Breda \& Preto, 2011), deeper marine sedimentation continued in the Tolmin (sensu Cousin, 1981; see explanation in Goričan et al., 2012) and Bled basins (Cousin, 1981; Goričan et al., 2012), while another major Triassic basin, the Tarvisio Basin, was additionally established during the Carnian (Gianolla et al., 2010; Gale et al., 2015).

The least known of the three major Triassic basins in the eastern Southern Alps is the Bled Basin, which was established on the basis of the continuous, upper Anisian to Hauterivian deeper marine succession preserved in the Pokljuka Nappe and exposed on the Pokljuka Mountain Plateau and in the surroundings of Bled (Cousin, 1981; Kukoč et al., 2012; Goričan et al., 2012; Kukoć, 2014; Goričan et al., 2018). From the latest Ladinian to the Early Jurassic, a unit consisting largely of thin- to medium-thick beds of limestone with chert nodules several hundreds of meters thick, known as the Zatrnik Formation, was deposited. This lithostratigraphic unit was first mentioned by Diener (1884), and then by Härtel (1920), and Budkovič (1978). The name presently used was introduced by Cousin (1981), but later authors also referred to this unit as Pokljuka Limestone or the Pokljuka Formation (Dozet \& Buser, 2009, with references). The latest Ladinian to Norian age of the lower and middle part of the Zatrnik Formation was determined on the basis of bivalves (Buser, 1980), radiolarians (Gale et al., 2019), and conodonts (KolarJurkovšek et al., 1983; Ramovš, 1986, 1998; Gale et al., 2019). The uppermost part of the Zatrnik Formation differs from the rest of the formation in the abundance of echinoderm debris (the "Hierlatz facies" in Budkovič, 1978). The Early Jurassic age of this facies was previously determined on the basis of brachiopods, ammonites, bivalves, fish remains, and foraminifer Involutina liassica (Jones) (Härtel, 1920; Budkovič, 1978). However, more detailed sedimentological and biostratigraphic research of the upper part of the Zatrnik Formation was never performed.
The uppermost part of the Zatrnik Formation is located below the Javorski vrh peak, SE of the Zajamniki mountain pasture in what we refer to here as the Zajamniki section. The upper part of this section was previously described by $\mathrm{Ku}-$ koč (2014) in an unpublished thesis. The section starts with the micritic limestone-dominated "classical" Zatrnik Formation, spans the "Hierlatz facies" of the Zatrnik Formation, and ends with the Ribnica Breccia overlying the Zatrnik Formation. This paper presents the sedimentological and micropaleontological analysis of the logged section, thereby providing some new information on the evolution and sedimentary dynamics of the Bled Basin.

\section{Geological Setting and Lithostratigraphy}

Structurally, the area of the Pokljuka plateau belongs to the Southern Alps (Placer, 2008), more precisely, to the Pokljuka Nappe (Buser, 1986). The Pokljuka Nappe is thought to have formed during Dinaric thrusting and is positioned above the Krn Nappe, which is characterised by a thick succession of Triassic to Lower Jurassic shallow marine carbonates, followed by Middle Jurassic - Cretaceous condensed carbonates (Šmuc, 2005; Šmuc \& Rožič, 2010). The primary thrust contacts of the Pokljuka Nappe are completely obliterated by post-thrust faults, and the platform and the basin contacts are along NW-SE and NW-SE-directed steep faults (Goričan et al., 2018). As already mentioned, the Pokljuka Nappe comprises a continuous Anisian to Hauterivian basinal succession (Fig. 2). The succession above the Zatrnik Formation continues with the Ribnica Breccia unit. Its Pliensbachian age was determined on the basis of the foraminifer Involutina liassica (Jones) found in clasts and the regional comparison (Kukoč, 2014; Goričan et al., 2012). The succession continues with the uppermost Bajocian- lower Tithonian radiolarite, which is succeeded in turn by upper Tithonian - ? Berriasian Biancone (calpionellid) limestone with chert nodules and marl interlayers. The calpionellid limestone is overlain by the Bohinj Formation (Kukoč et al., 2012), comprising limestone breccia, and calcarenite. Finally, the ?upper Berriasian - Hauterivian flysch-type succession follows (Fig. 2). This succession is informally divided into two parts. The lower part consists of pelagic limestone with marl interlayers and calarenites. The upper part (Studor Formation) is characterized by the presence of sandstone beds increasing in proportion towards the top (Kukoč, 2014; Goričan et al. 2018). Ophiolitic detritus is present 


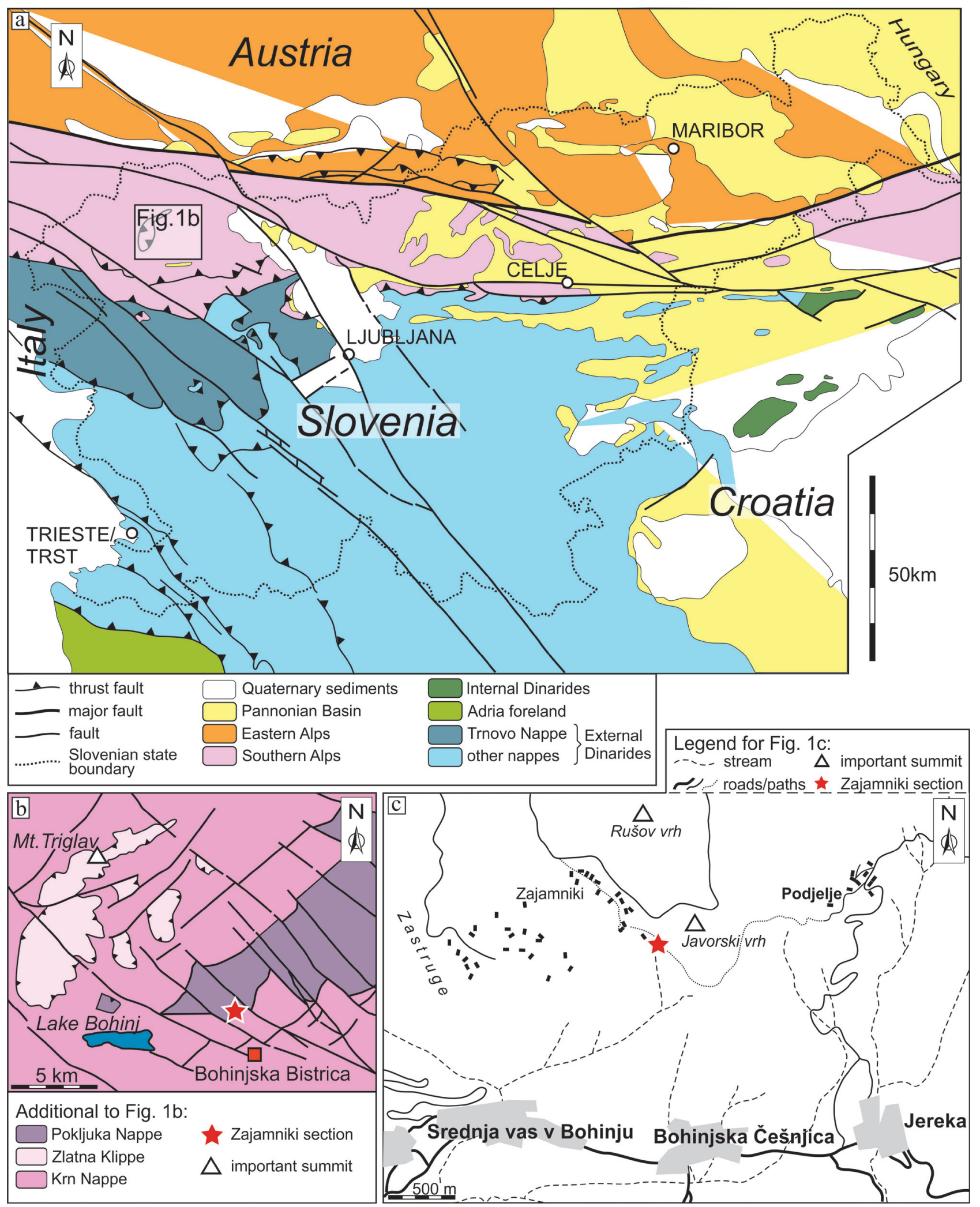

Fig. 1. Geographic and structural position of the studied section. a) Structural subdivision of the Alpine-Dinaric-Pannonian Transition Zone (after Placer, 2008); b) Structure of the central Julian Alps (after Goričan et al., 2018) with the position of the Zajamniki section marked with a star symbol.

from the Bohinj Formation upwards, indicating the ocean-ward position of the Bled Basin (Kukoč et al., 2012; Goričan et al., 2012, 2018).

The studied Zajamniki section is located on the southern slopes of the Pokljuka mountain plateau (1000-1600 m.a.s.l.) in the eastern part of the Julian Alps in NW Slovenia (Fig. 1). The section starts at $46^{\circ} 18^{\prime} 33.24^{\prime \prime}$ lat., $13^{\circ} 56^{\prime} 24.86^{\prime \prime}$ long., and ends at $46^{\circ} 18^{\prime} 30.33^{\prime \prime}$ lat., $13^{\circ} 56^{\prime} 29.21^{\prime \prime}$ long. On the basis of the geological map, published in Goričan et al. (2018), the succession is in overturned position. 
Studor Fm.

(mudstone, sandstone, breccia;

?upper Berriasian-

Hauterivian)

„Transitional Unit“ (micritic limestone with marl interlayers and thin-bedded calcarenites with siliciclastic component; Berriasian)

Bohinj Fm. (resediments; uppermost Tithonian-Berriasian)

Biancone Lst.

(platy micritic limestone with marly bedding planes; upper Tithonian-?Berriasian)

radiolarite (uppermost Bajocianlower Tithonian)

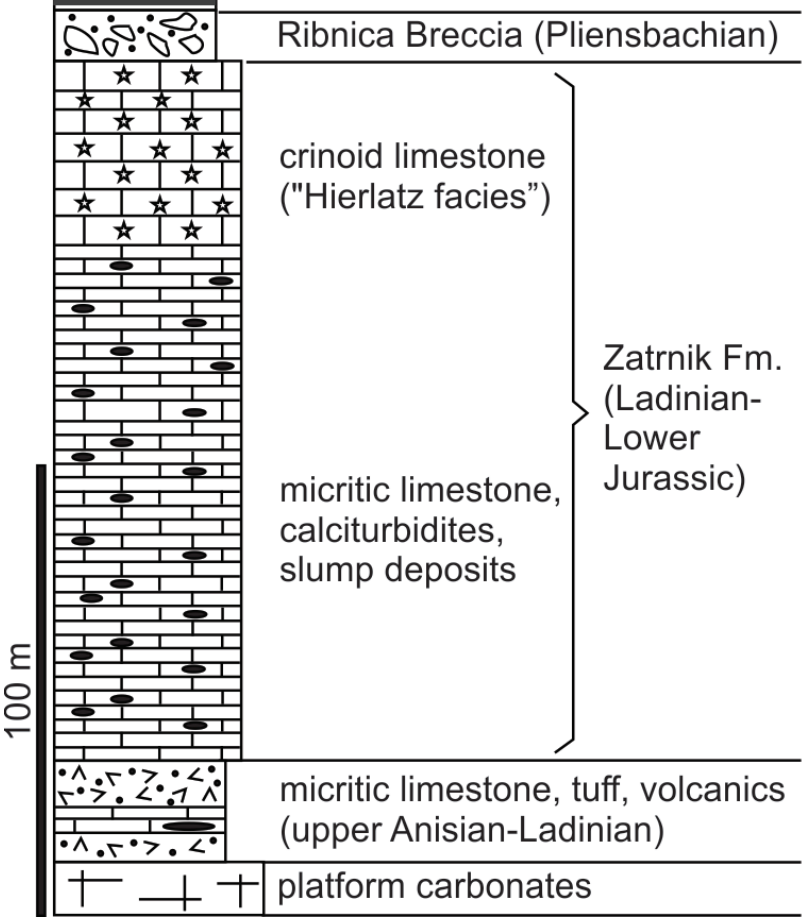

Fig. 2. Lithostratigraphic column of the Bled Basin. Modified after Goričan et al. (2018)

\section{Materials and methods}

The sedimentological investigation of the logged section is based on 57 thin sections $47 \times$ $28 \mathrm{~mm}$ in size. Fine-grained calcarenite was sampled rather than mudstone varieties, so there is some bias to the described microfacies assemblage. Carbonates were classified according to classification by Dunham (1962). When adding components to the textural name, we follow suggestion by Wright (1992) and name the predominant grain type first. Point-counting of 300 points in a random grid was performed in JMicroVision v1.2.7 (Copyright 2002-2008 Nicolas Roduit) software. Due to the assumed latest Triassic age for the lower part of the logged succession, five standard-size conodont samples were taken. They were treated in diluted (cca. 8\%) acetic acid at the Geological Survey of Slovenia. All conodont samples were negative.

\section{Lithological description}

The total stratigraphic thickness of the $\mathrm{Za}-$ jamniki section measures approximately $75 \mathrm{~m}$ (Figs. 3, 4a). It is divided into three parts: the "classical" Zatrnik Formation (up to $25.8 \mathrm{~m}$ ), the "Hierlatz facies" of the Zatrnik Formation (from 25.8 to $72.0 \mathrm{~m}$ ), and the Ribnica Breccia (above $72 \mathrm{~m}$ ). The "classical" Zatrnik Formation is dominated by beige-coloured, predominantly medium bedded micritic (mudstone to very fine-grained packstone and grainstone) limestone (Fig. 4b). Chert nodules represent up to $30 \%$ of the rock, with the exception of two thinner beds, which are completely silicified. Amalgamation surfaces are common. In addition to micritic limestone, two very thick beds of clast-supported breccia (rudstone?) are present in the lowermost part in beds up to $3.3 \mathrm{~m}$ thick. Breccia is normally graded. Clasts are moderately sorted. Clasts are beige, grey, and pale pink in colour, in compositions corresponding to the underlying lithologies. Matrix is subordinate and ochre in colour. Medium-thick beds of fine-grained calcarenite predominate over micritic limestone between the $16^{\text {th }}$ and $21^{\text {st }}$ metres of the section. Microfacies types from this first part of the section are dense intraclastic-bioclastic wackestone to packstone (MF1), bioclastic-pelletal packstone (MF2), peloid packstone (MF3), intraclastic grainstone (MF4), and poorly sorted intraclastic packstone to floatstone (MF5) (Table 1; Fig. 5).

The "classical" Zatrnik Formation is followed by a thick slumped (Fig. 4c) interval of micritic and crinoid-rich limestone which is strongly silicified in some parts. Such lithology was pre- 

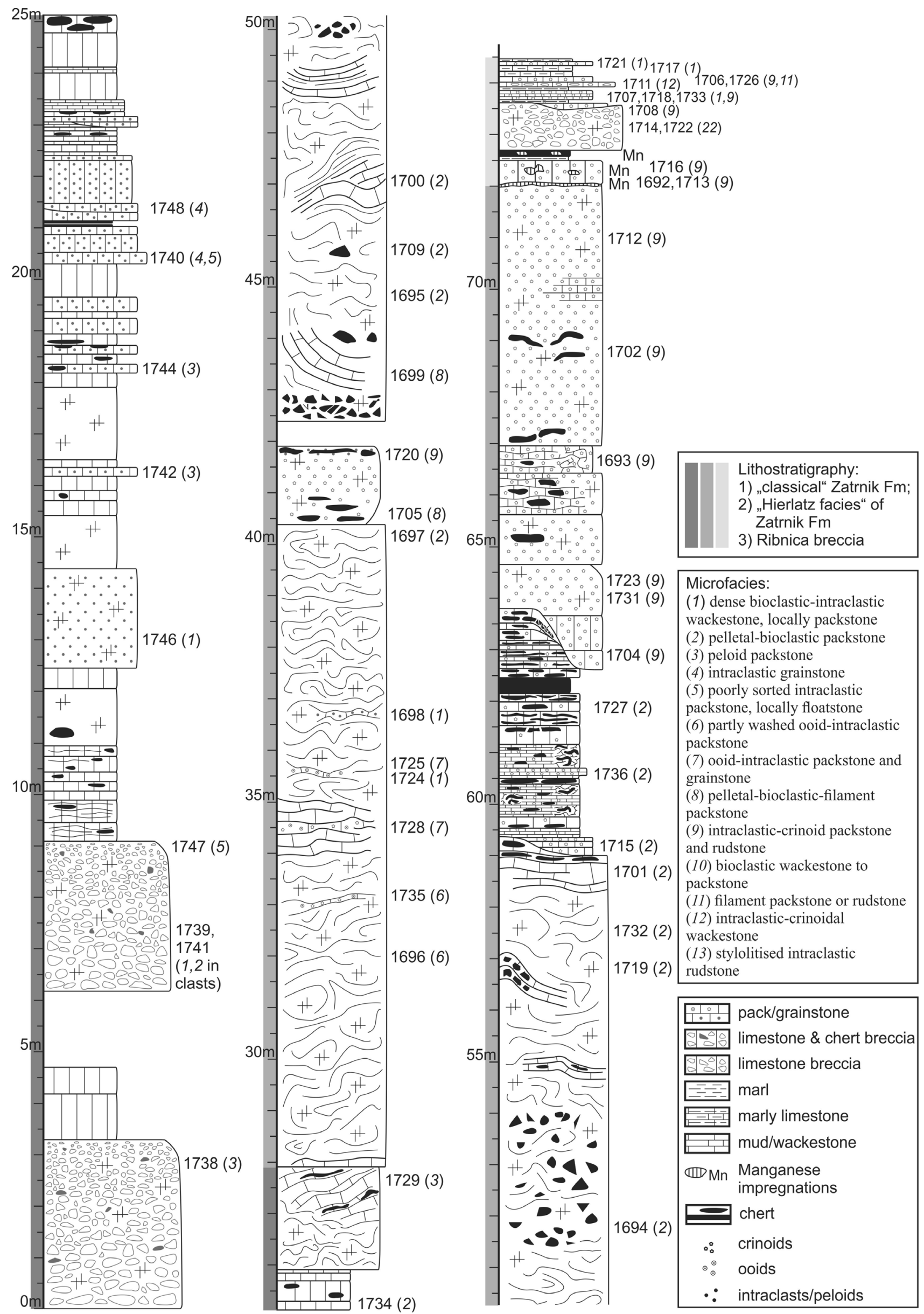

Fig. 3. Sedimentological log of the Zajamniki section. Numbers to the right of the lithology represent thin section numbers. The microfacies type is written in brackets next to the thin section number. For a description of microfacies types see Tables $1-3$. 

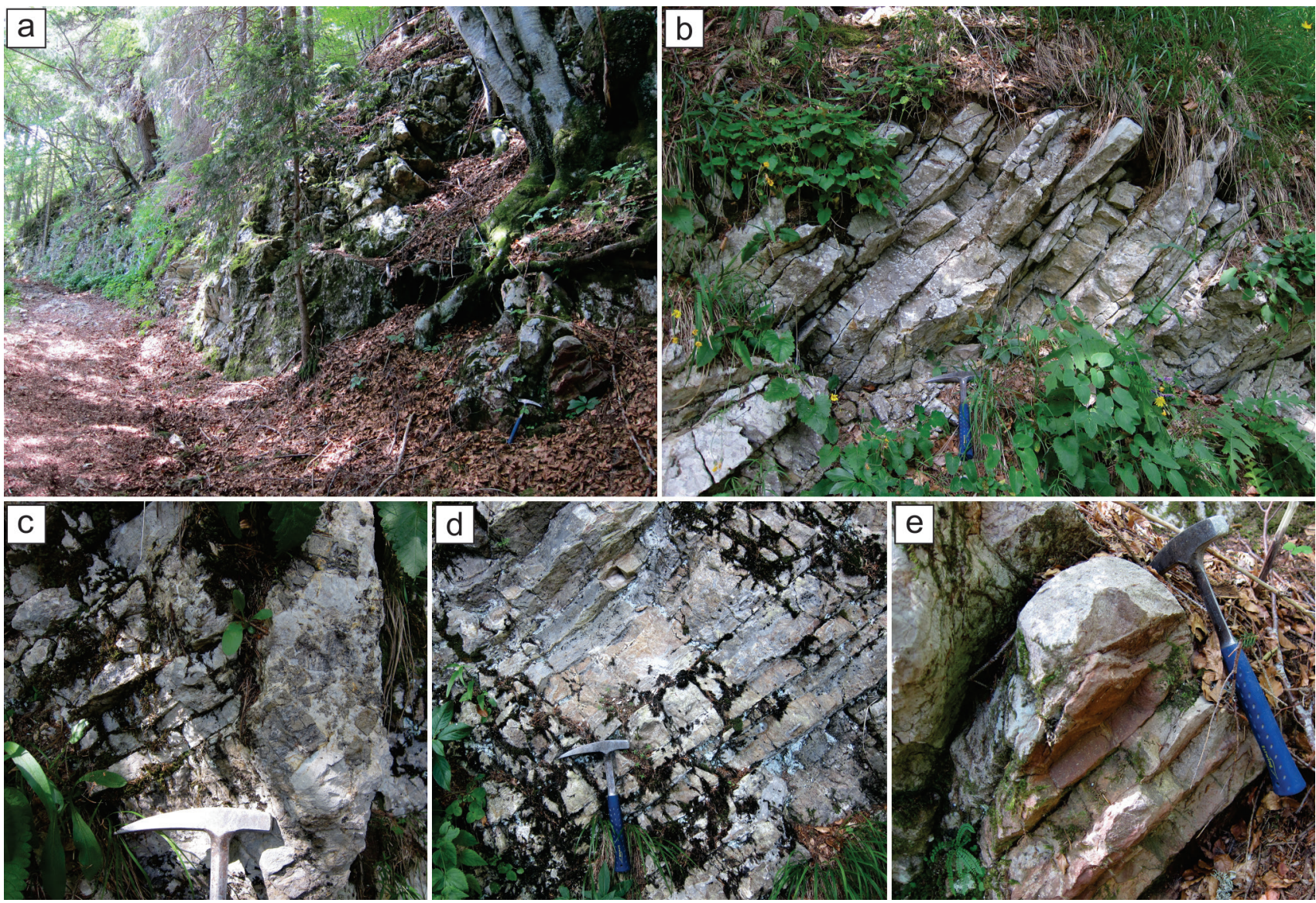

Fig. 4. Field photographs of the section. a: View on the section from the contact with the Ribnica Breccia (hammer). b: Micritic limestones of the Zatrnik Formation. c: Slump scar and slump breccia. d: Silicified limestone of the "Hierlatz facies". e: Contact with the Ribnica Breccia.

Table 1. Descriptions of microfacies (MF) types of the upper Zatrnik Formation from the first $26 \mathrm{~m}$ of the Zajamniki section.

\begin{tabular}{|c|c|}
\hline MF type & Description \\
\hline $\begin{array}{l}\text { dense intraclastic- } \\
\text { bioclastic } \\
\text { wackestone, } \\
\text { locally packstone } \\
\text { (MF1) }\end{array}$ & $\begin{array}{l}\text { Grains occupy } 35-40 \% \text { of the area of view. They are medium sorted, in some samples poorly } \\
\text { sorted due to the presence of larger intraclasts, calcimicrobes and large echinoderm ossicles. } \\
\text { Micritic intraclasts (peloids) predominate among grains. They are subangular to subround- } \\
\text { ed. Only approximately } 5 \% \text { of the volume is occupied by echinoderm plates, foraminifers, } \\
\text { calcimicrobes, fragments of brachiopods, Tubiphytes-like microproblematica. Some echi- } \\
\text { noderm plates show small borings near their margins. Echinoderm plates are rimmed by } \\
\text { syntaxial cement. }\end{array}$ \\
\hline
\end{tabular}

Figures

While some samples show vague parallel lamination, others appear bioturbated. Micritic matrix is full of small pellets. Highly notable are particles of calcite monocrystals, which are the largest particles in this MF. They are locally abundant enough to be in point-contacts and forming a great proportion of the rock (in fact, gradually passing into intraclastic-cribioclastic-pelletal noid packstone). They are of various sizes (largest $0.85 \mathrm{~mm}$ ), randomly oriented, and angupackstone lar. Brownish inner parts are visible in some, probably representing echinoderm fragments, (MF2) later overgrown by calcite. Many of them, however, cannot be determined. Ostracods, small foraminifers (nodosariids, Lenticulina, Textulariidae, Ophthalmidiidae) are rare. Sponge spicules are locally present. Fossils are mostly fragmented and/or disarticulated. Thin section 1694 also contains a singular angular clast of chert. Echinoderm plates are rimmed by syntaxial cement.

Some samples show bioturbations, where peloid packstone intermixes with mudstone. Peloids
occupy $44 \%$ of area. They are very well sorted and in point contacts. Most are $0.08-0.1 \mathrm{~mm}$ peloid packstone in size. Echinoderm plates represent $4 \%$ of the area, and thalli of Thaumatoporella and foraminifers each $1 \%$. The latter include Valvulinidae, Siphovalvulina sp., ?Radoicicina sp., Earlandia sp., glomospiral forms, and "Agerina". Also rare are calcimicrobes and ostracods.

Grains represent $50 \%$ of the area. Sorting is medium to very good. Wide laminae, differing intraclastic $\quad$ in size grains are visible. Small micritic intraclasts represent most of the grains. They are grainstone Gaudryina sp., Earlandia sp., Meandrovoluta asiagoensis Fugagnoli \& Rettori), spari(MF4) tic particles, echinoderms, ostracods, calcimicrobes, and Thaumatoporella are very rare. tic particles, echinoderms, ostracods, calcimicrobes,
Intergranular space is filled with drusy mosaic spar.

Grains are poorly sorted. Large calcimicrobes, micritic intraclasts, and also some echinoderm plates are over $2 \mathrm{~mm}$ long, and the largest reach $4.2 \mathrm{~mm}$ in size. Grains are chaotically

poorly sorted intraclastic packstone, locally floatstone (MF5) distributed, floating or supporting each other in wackestone and packstone matrix. Besides the clasts mentioned, Thaumatoporella, brachiopod fragments, foraminifers (Pfenderinidae, Reophax sp., Siphovalvulina gibraltarensis Boudagher-Fadel, Rose, Bosence \& Lord, Everticyclammina? sp.), sponge fragments, and gastropods are present. Echinoderm plates are rimmed by syntaxial cement. 

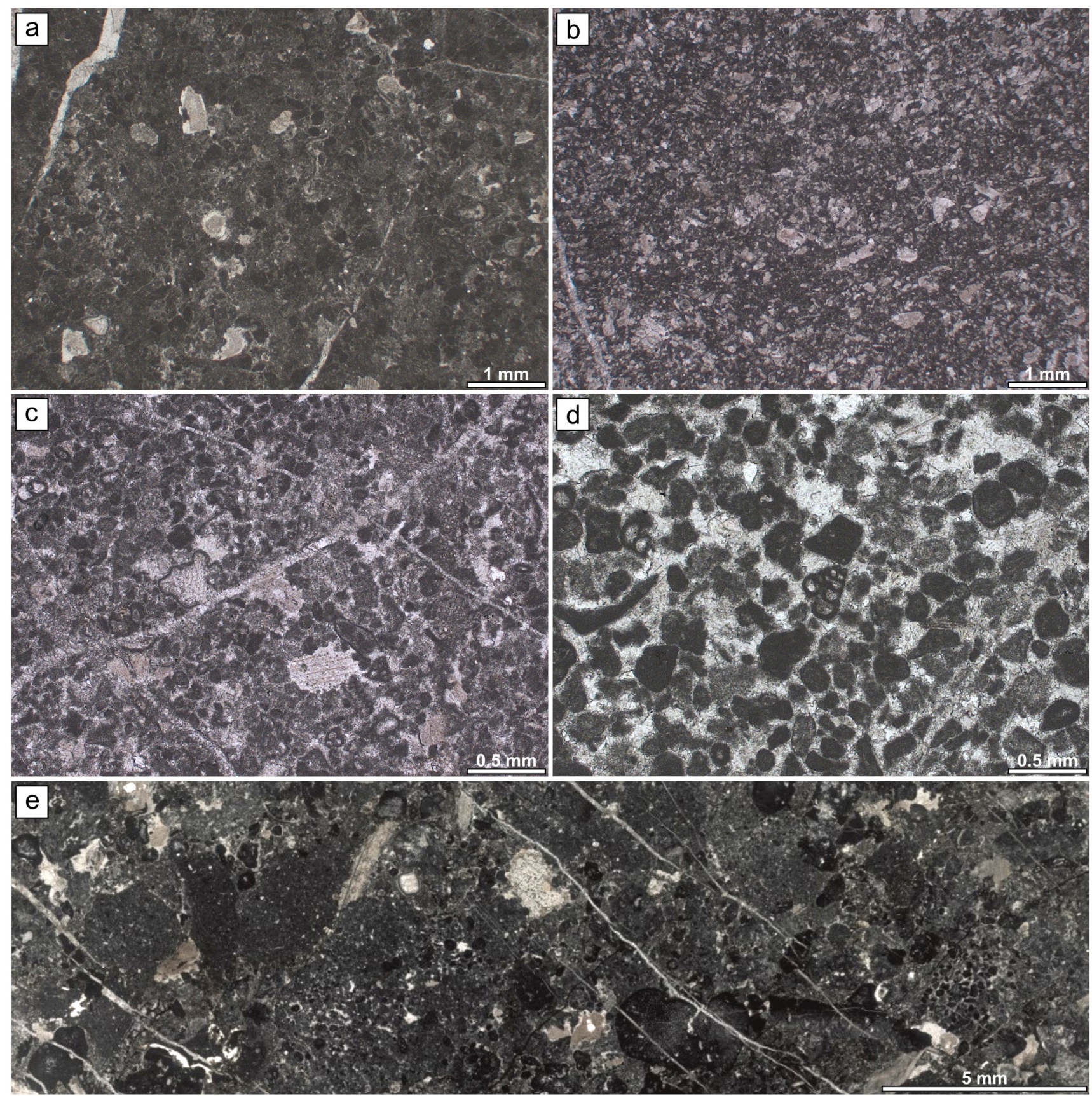

Fig. 5. Microfacies types of the upper Zatrnik Formation from the first $26^{\text {th }}$ meters of the Zajamniki section. a: Dense intraclastic-bioclastic wackestone, locally packstone. Thin section 1746. b: Bioclastic-pelletal packstone. Thin section 1715 . c: Peloid packstone. Thin section 1744. d: Intraclastic grainstone. Thin section 1740. e: Poorly sorted intraclastic floatstone. Thin section 1747.

viously marked as the "Hierlatz facies" (Goričan et al., 2012), or as the upper part of the Zatrnik Formation, rich in echinoderms (Kukoč, 2014; Goričan et al., 2018). The base of the "Hierlatz facies" is here set at the change in colour (beige colour is substituted by light pink). Thin beds dominate. Parallel lamination is preserved in completely silicified medium thick beds between the $61^{\text {st }}$ and $63^{\text {rd }}$ meters of the section (Fig. $4 d$ ). A sealed paleofault or slump scar outcrops at the $63^{\text {rd }}$ meter. Here, the fine-grained limestone beds are downfolded and chert nodules brecciated. The space on the other side of the discontinuity is filled by bedded coarse calcarenite. In addition to the already described peloid packstone, dense intraclastic-bioclastic wackestone to packstone, and bioclastic-pelletal packstone, the microfacies assemblage in this part of the section also comprises partly washed intraclastic-oolitic packstone (MF6), intraclastic-oolitic packstone and grainstone (MF7), filament-bioclastic-pelletal packstone (MF8), and crinoid-intraclastic packstone and rudstone (MF9) (Table 2; Fig. 6).

The uppermost $2.2 \mathrm{~m}$ of the section belong to the Ribnica Breccia. Impregnations with Fe-Mn oxides start at the upper bedding plane of the 
Table 2. Description of microfacies (MF) types of the "Hierlatz facies" of the upper Zatrnik Formation between the $26^{\text {th }}$ and $72^{\text {nd }}$ meters of the Zajamniki section. In addition to these, previously described peloid packstone, dense bioclastic-intraclastic wackestone to packstone, and pelletal-bioclastic packstone are also present (see Table 1).

MF type Description Figures

Packstone of this type appears more poorly sorted and with much less intergranular cement than in intraclastic-oolitic packstone and grainstone, but the general composition of the two is similar. Grains represent $70 \%$ of the area. They are mostly in point contacts, some in long or concavo-convex contacts. Sorting is poor, with most grains ranging between $0.150 \mathrm{~mm}$ and $1.5 \mathrm{~mm}$. The largest grain in thin section measures $3.7 \mathrm{~mm}$. The dominant grains are sub- to well-rounded micritic intraclasts $(60 \%$ of area). Some (10\%) of the latter possibly represent micritic ooids. Oolitic envelops are locally visible, but more common are what appears to be cortices crushed by compaction. Calcimicrobes represent $2 \%$ of the total area, as well as echinoderms and mollusc fragments. Calcimicrobes are abraded, some partly overgrown by oolitic envelops. Foraminifers (Siphovalvulina colomi colomi Boudagher-Fadel, Rose, Bosence \& Lord, Siphovalvulina sp., ?Everticyclammina sp., Trocholinidae), brachiopods and gastropods are also present. Echinoderm plates have micritic outlines, are bioeroded, or overgrown by syntaxial rim cement.

intraclastic-oolitic

packstone

(MF6)

Grains are in point-contacts. In thin section 1725 they are moderately sorted, whereas in thin section 1728 they display a bimodal distribution in size due to the extra presence of small peloids. The grain size is between 0.175 and $0.95 \mathrm{~mm}$. The largest grains are $2.27 \mathrm{~mm}$ in diameter. Micritic intraclasts represent $45 \%$ of area. They are subrounded to well-rounded, in thin section 1728 also angular. The well-rounded ones could also be completely micritised ooids. Ooids are the second most common clasts (25\%). Most are of tangential type, but some are recrystallized into radial. They have between 2 and 16 envelops, which are often partly bioeroded. Their nuclei contain micritic intraclasts, calcimicrobes, bioeroded sparitic particles, gastropods, foraminifers, or dasycladacean algae. Rarely or only sporadically present are sparitic bioclasts, foraminifers, clasts of Pseudolithocodium/Lithocodium, echinoderm plates, and gastropods. Foraminifers within and outside ooids are Siphovalvulina ex gr. gibraltarensis Boudagher-Fadel, Rose, Bosence \& Lord, S. ex gr. variabilis/colomi Boudagher-Fadel, Rose, Bosence \& Lord, Valvulinidae, ?Everticyclammina sp., "Nautiloculina" sp., Meandrovoluta asiagoensis Fugagnoli \& Rettori, planispiral porcellaneus forms with porcelaneous walls, Trocholinidae, and Lagenida were recognised. Intergranular space is filled with drusy mosaic cement. Locally, grains are rimmed by granular cement, and the remaining intergranular space filled with micrite. Echinoderms are overgrown by syntaxial rim cement.

(MF7)

This MF is similar to bioclastic-pelletal packstone (see Table 1), but with a significant amount $(20-40 \%$ of area) of filaments. These are disarticulated, concordant to bedding plane, and roughly uniform in size. The calcitic particles are here clearly echinoderm plates rimmed by syntaxial cement. The two MF types are most like members of the

filament-boioclasticpelletal packstone. (MF8)
$5 \mathbf{a}$ same MF group, differing in different proportions of components.

Concerning the composition, this MF is comparable to bioclastic-pelletal packstone, but with larger intraclasts and crinoids. Within the given level, grains are well sorted. Vertically, however, the grain size varies from 0.25 to over $3 \mathrm{~mm}$. Grading is clearly visible in some samples. Grains represent $85 \%$ of the area. They are in long to stylolitic contacts. Crinoids represent $60 \%$ of the area. Intraclasts represent $25 \%$ of area. They comprise various lithologies: a) mudstone, b) fenestral mudstone, c) bioclastic wackestone with ostracods and sparitic particles, d) bioclastic wackestone with ostracods, sparitic particles, pellets and small foraminifers (Agerina sp., Planispirillina sp.), e) bioclastic wackestone with sparitic particles, spicules, nodosariids, and juvenile ammonites, f) bioclastic wackestone with sponge spicules, juvenile ammonites and filaments, g) peloid packstone, h) well sorted peloid grainstone, i) peloid-cortoid grainstone, j) calcisiltite. Besides intraclasts, finer-grained varieties of MF 9 contains rare ostracods and foraminifers (nodosarids, Pseudonodosaria, ?Epistominidae, Lenticulina sp.). Echinoderm plates are rimmed by syntaxial cement. Manganese nodules and impregnations are present in some samples.

packstone and

rudstone

(MF9)

. 

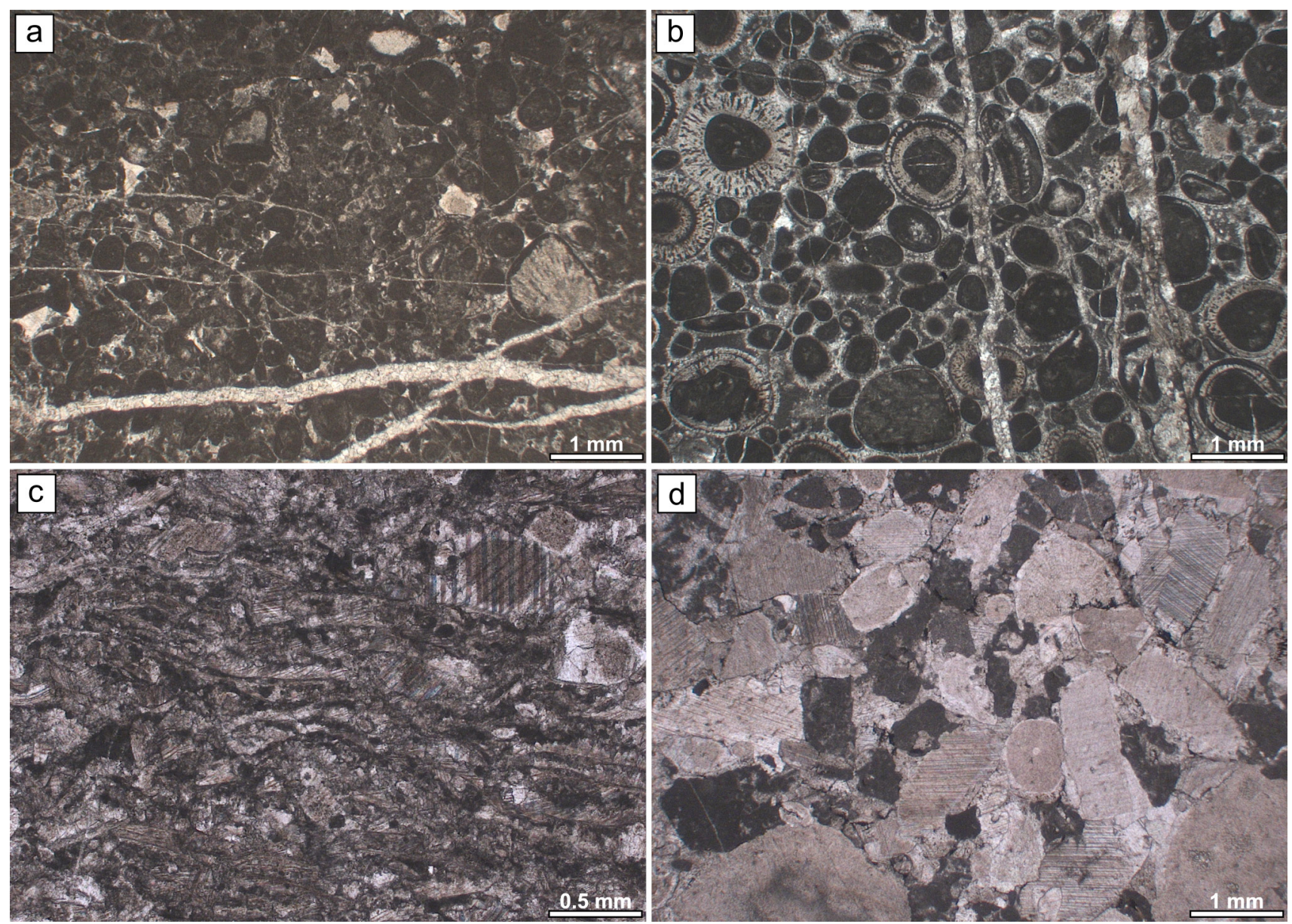

Fig. 6. Microfacies (MF) types of the uppermost Zatrnik Formation. a: Partly washed intraclastic-oolitic packstone. Thin section 1696. b: Intraclastic-oolitic packstone, partly washed. Thin section 1725. c: Filament-bioclastic-pelletal packstone. Thin section 1699. d: Crinoid-intraclastic packstone and rudstone. Thin section 1712.

Table 3. Description of microfacies (MF) types of the Ribnica Breccia from the Zajamniki section. In addition to these, intraclastic-crinoid packstone and rudstone is also present (see descriptions in Table 2).

\begin{tabular}{llc}
\hline MF type & Description & Figures \\
\hline
\end{tabular}

Grains represent $30-50 \%$ of the area. Echinoderm plates predominate $(60-70 \%$ of bioclastic grains). Micritic intraclasts form approximately $30 \%$ of grains, foraminifers $1 \%$ of grains, and ostracods $5 \%$ of grains. In packstone variety, peloids occupy additional $10 \%$ packstone of the surface area, and limonitised oncoids locally $5 \%$ of surface. Very rare are appackstone tychi. Among foraminifers are most common lagenids, including Lenticulina, and less
(MF10) numerous Ophthalmidium and Valvulinidae. Foraminifers are commonly broken, and many bioclasts are bioeroded. Intergranular space is filled with micritic matrix, which is limonitised in some levels.

filament packstone Filaments are even more abundant and densely packed together than in filament-bioclasand rudstone tic-pelletal packstone. Filaments represent approximately $90 \%$ of the surface, echino(MF11) derm plates $5-10 \%$, and peloids only around $2.5 \%$. The amount of micritic matrix is very small due to grains being in long contacts.

intraclasticcrinoid

wackestone

(MF12)
Grains represent $60 \%$ of the area. Grains are randomly distributed within the matrix, most are matrix-supported. The most common grains are various intraclasts (21\%): a) mudstone, b) bioclastic wackestone with filaments and juvenile ammonites, c) wackestone with crinoids, and peloid grainstone. Echinoderm plates occupy $13 \%$ of the area. Ferromanganese nodules cover $3.5 \%$ of the area. The rest of the volume is taken by filaments, ostracods, and foraminifers (nodosariids, Lenticulina). Margins of clasts are often covered by opaque mineral (ferromanganese or limonite crust). stylolitised intraclastic rudstone (MF13)
Clasts in thin sections are over $3 \mathrm{~cm}$ in size. They are in limonitised stylolitic contacts. Intraclasts comprise light pink and beige bioclastic wackestone with sponge spicules, echinoderms, gastropods, nodosariids, and juvenile ammonites. Less common are intraclasts of peloidal-bioclastic wackestone. 6e-f 


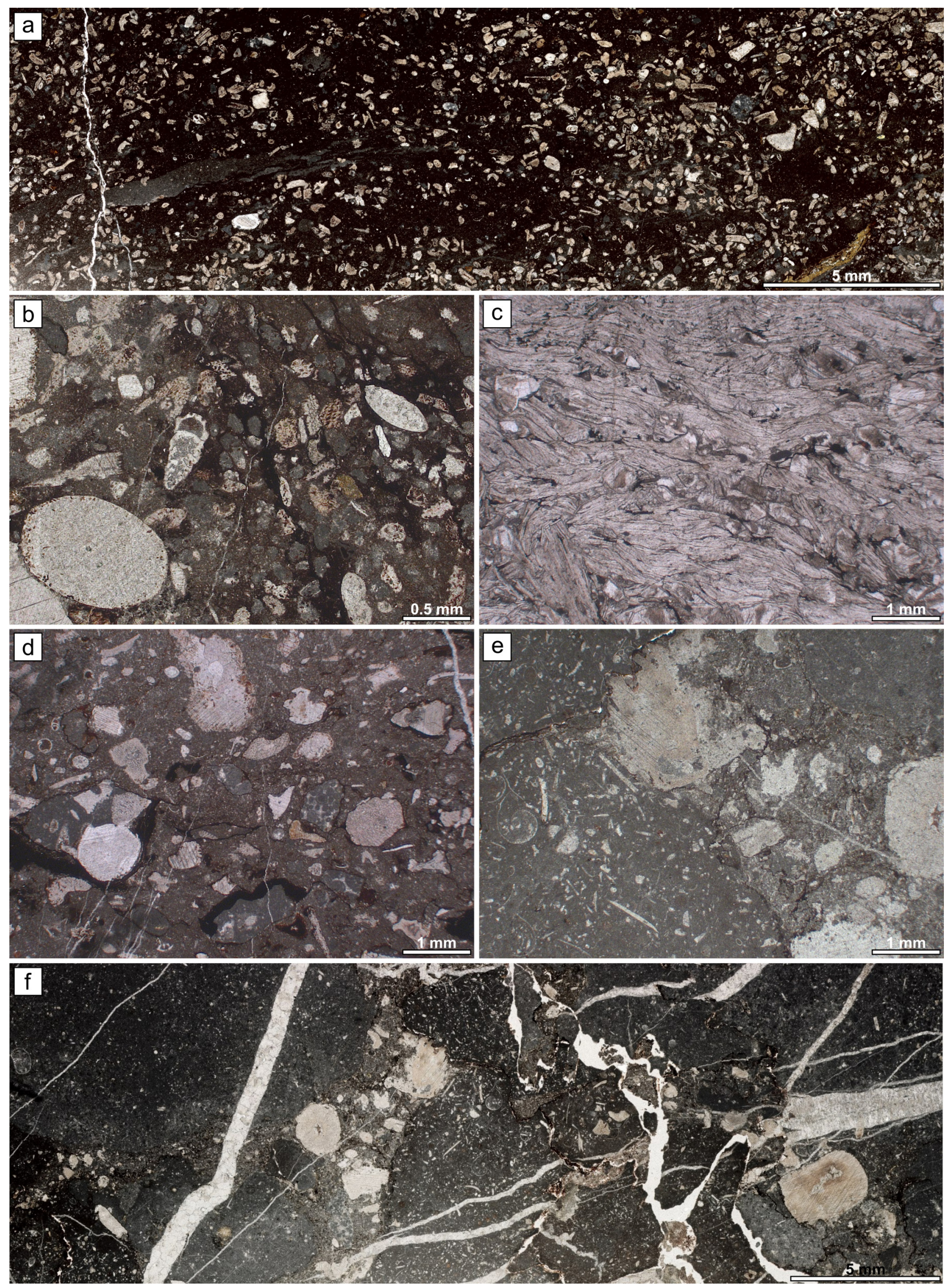

Fig. 7. Microfacies (MF) types of the Ribnica Breccia. a-b: Bioclastic wackestone to packstone. Thin sections 1717 and 1733 respectively. c: Filament packstone or rudstone. Thin section 1726. d: Intraclastic-crinoidal wackestone. Thin section 1711. e-f: Stylolitised intraclastic rudstone. Thin section 1714. 
Table 4. Distribution of foraminiferal species in the uppermost Zatrnik Formation and in the Ribnica Breccia in the Zajamniki section.

\begin{tabular}{|c|c|c|c|c|c|c|c|c|c|c|c|c|c|c|c|c|c|c|c|c|c|}
\hline \multicolumn{2}{|c|}{ Foraminifers } & 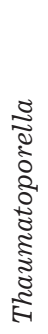 & 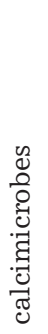 & 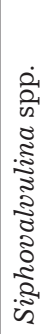 & 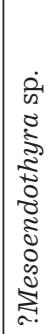 & 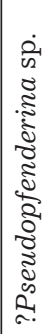 & 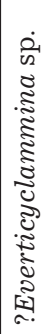 & 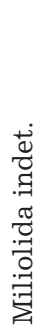 & 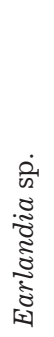 & 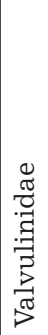 & 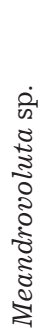 & 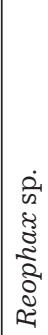 & 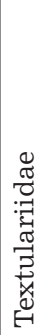 & 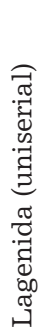 & 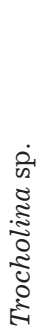 & 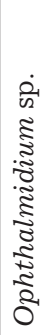 & 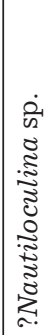 & 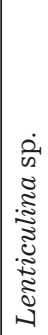 & 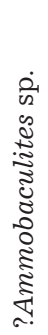 & 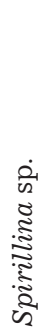 & 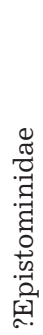 \\
\hline \multirow{10}{*}{ 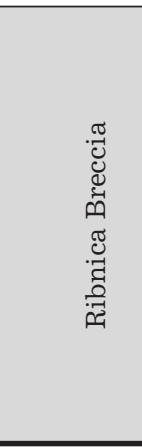 } & 1721 & & & & & & & & & - & & & & - & & - & & - & & & \\
\hline & 1717 & & & & & & & & & & & & & & & & & & & & $\bullet$ \\
\hline & 1706 & & & & & & & & & & & & & $\bullet$ & & & & $\bullet$ & & & $\bullet$ \\
\hline & 1711 & & & & & & & & & & & & & - & & & & $\bullet$ & & & \\
\hline & 1737 & & & & & & & & & & & & & - & & & & • & & & \\
\hline & 1733 & & & & & & & & & & & & & & & & & $\bullet$ & & & \\
\hline & 1718 & & & & & & & & & & & & & . & & & & & & & - \\
\hline & 1707 & & & & & & & & & & & & & $\bullet$ & & & & $\bullet$ & & & \\
\hline & 1708 & & & & & & & & & & & & & $\bullet$ & & $\bullet$ & & $\bullet$ & & $\bullet$ & \\
\hline & 1722 & & & & & & & & & & & & & - & & & & & & & \\
\hline \multirow{14}{*}{ 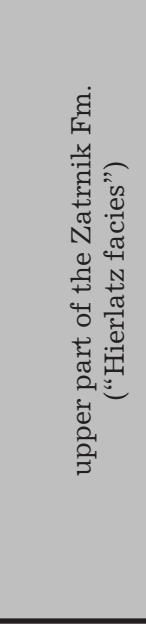 } & 1693 & & & & & & & & & & & & & • & & & & & & & \\
\hline & 1704 & & & & & & & & & & & & & & & & & & $\bullet$ & & \\
\hline & 1727 & & & & & & & & & & & & $\bullet$ & & & & & & & & \\
\hline & 1701 & & & & & & & & & & & & & - & & & & & & & \\
\hline & 1719 & & & & & & & & & & & & & & & & & $\bullet$ & & & \\
\hline & 1695 & & & & & & & & & & & & & - & & $\bullet$ & & & & & \\
\hline & 1697 & & & & & & & & & & & & & $\bullet$ & & & & & & & \\
\hline & 1698 & & & & & & & & & & & & $\bullet$ & $\bullet$ & & & & & & & \\
\hline & 1725 & & & $\bullet$ & & & $\bullet$ & & & $\bullet$ & $\bullet$ & & & & $\bullet$ & & $\bullet$ & & & & \\
\hline & 1724 & & & & & & & & & & & & & . & & $\bullet$ & & & & & \\
\hline & 1728 & & & & & & & $\bullet$ & & & & & & $\bullet$ & & & & & & & \\
\hline & 1735 & & & $\bullet$ & & & & & & $\bullet$ & & & & & $\bullet$ & & & & & & \\
\hline & 1696 & & & $\bullet$ & & & $\bullet$ & & & & & & & & & & & & & & \\
\hline & 1729 & & & & & & & & $\bullet$ & & & & & $\bullet$ & & & & & & & \\
\hline \multirow{10}{*}{ 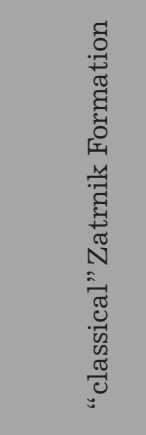 } & & & & & & & & & & & & & & & & & & & & & \\
\hline & 1748 & $\bullet$ & & $\bullet$ & & & & & & $\bullet$ & $\bullet$ & & & & & & & & & & \\
\hline & 1740 & $\bullet$ & - & $\bullet$ & & - & & & $\bullet$ & & $\bullet$ & $\bullet$ & $\bullet$ & & & & & & & & \\
\hline & 1744 & $\bullet$ & & $\bullet$ & & & & & & & & & & & & & & & & & \\
\hline & 1742 & $\bullet$ & & $\bullet$ & & & & & $\bullet$ & $\bullet$ & & & & & & & & & & & \\
\hline & 1746 & & & & $\bullet$ & & & $\bullet$ & & & & & & & & & & & & & \\
\hline & 1747 & $\bullet$ & $\bullet$ & $\bullet$ & & & $\bullet$ & & & & & & & & & & & & & & \\
\hline & 1739 & & & & & & & & & & & & & & & & & & & & \\
\hline & 1741 & $\bullet$ & $\bullet$ & $\bullet$ & $\bullet$ & $\bullet$ & & & & & & & & & & & & & & & \\
\hline & 1738 & $\bullet$ & $\bullet$ & & & & & & & & & & & & & & & & & & \\
\hline
\end{tabular}

\section{Fossils and age of the uppermost Zatrnik Formation}

The age of the investigated interval was determined on the basis of benthic foraminifers. The stratigraphic distribution of foraminifers is shown in Table 4, and some are depicted in Figure 8. Overall, the foraminiferal assemblage consists of small benthic specimens that do not allow for precise stratigraphic control and are difficult to determine even at the genus or species level. The presence of Siphovalvulina spp. in the lower part of the section excludes Triassic age and instead places this part of the section already in the Jurassic (Septfontaine, 1988; Chiocchini et al., 1994). The Triassic-Jurassic boundary thus lies lower in the succession and is not present in the 

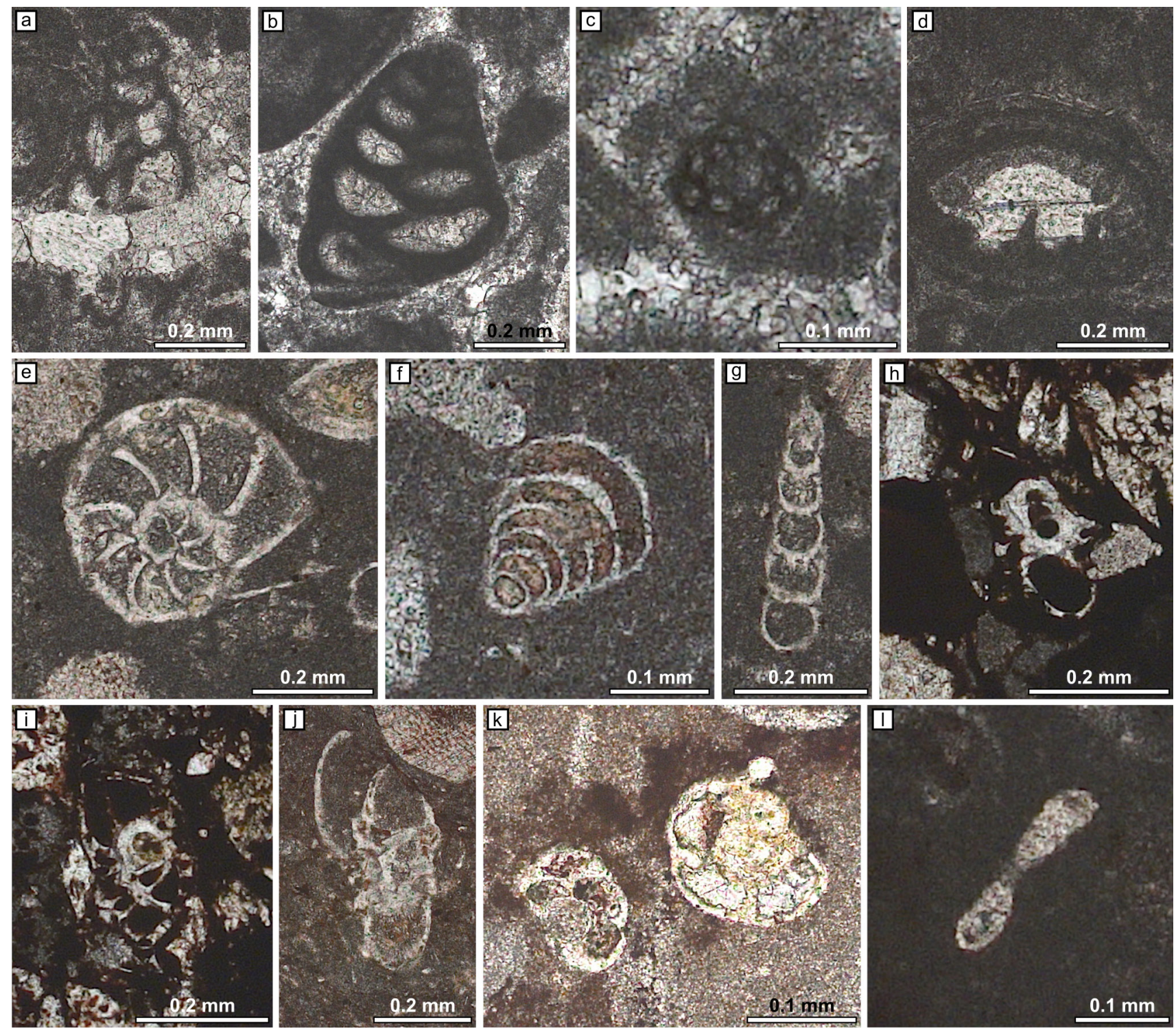

Fig. 8. Some characteristic foraminifers from the uppermost Zatrnik Formation and the Ribnica Breccia. a: Siphovalvulina sp. Thin section 1696. b: Valvulinidae. Thin section 1725. c: Meandrovoluta asiagoensis Fugagnoli \& Rettori. Thin section 1740. d: Trocholina sp. Thin section 1735. e: Lenticulina sp. Thin section 1721. f: Uniserial Lagenida. Thin section 1722 . g: Nodosariid Lagenida. Thin section 1721. h-k: ?Epistominidae. h-i: Thin section 1706. j: Thin section 1717. k: Thin section 1718. l: Spirillina sp. Thin section 1708.

logged section. Besides Siphovalvulina, which is the most typical genus in the lower part of the section, the assemblage from the first $21 \mathrm{~m}$ of the section also consists of a few other species, which, however, are determined with great uncertainty. These are dubious specimens of ?Everticyclammina, ?Mesoendothyra, ?Pseudopfenderina, Earlandia sp., and ?Reophax sp. Calcimicrobes and ?Thaumatoporella are also commonly present. Similar assemblages characterise the platform tops from the Lower Jurassic of the peri-Mediterranean area (e.g., Chiocchini et al., 1994; Mancinelli et al., 2005; Rožič et al., 2019). Siphovalvulina is present also in the lower samples of the "Hierlatz facies" of the Zatrnik Formation. Early Jurassic age is supported by rare occurrences of
Meandrovoluta asiagoensis Fugagnoli \& Rettori (Fugagnoli et al., 2003). Along with some of the previously present species, Trocholina sp., Valvulinidae, small Textulariidae, small elongated and at least partly uniserial Lagenida, and small ?Ophthalmidium occur. The highest occurrence of Siphovalvulina, Trocholina, Valvulinidae and ?Everticyclammina appears in sample 1725, which is $35.6 \mathrm{~m}$ from the base of the section. Foraminifers are then scarce until the base of the Ribnica Breccia. The assemblage of the Ribnica Breccia stands in contrast to the assemblages from the Zatrnik Formation. The most common genus is Lenticulina, commonly associated with small elongated Lagenida. Several specimens of small epistominids were also determined. 


\section{Sedimentological interpretation}

The absence of cross-laminations or other textures related to water depths above the storm weather wave base in the "classical" Zatrnik Formation in the Zajamniki section is consistent with the previous interpretation of the deposition within a deeper marine environment (Gale et al., 2019). Calcimicrobes, Tubiphytes-like microproblematica, Thaumatoporella, some foraminifers (Siphovalvulina, Meandrovoluta, Everticyclammina - see Gale, 2014) and also small borings on echinoderm plates suggest that at least some of the particles originate from within the photic zone. Due to the presence of parallel lamination in some beds, we suggest that microfacies types 1-4 (see Table 1) deposited as distal turbidites. Bioturbation suggests an oxygenated sea floor. It should be noted, again, that the sampling was biased towards calcarenites, thus possibly omitting hemipelagic microfacies types. The two thicker rudstone beds may represent the base of a turbidite or debris flow deposits (Mullins \& Cook, 1986). Slumps in the uppermost part of the Zatrnik Formation could indicate some intensive tectonic-controlled movements of the sea floor. Like the foraminifers Siphovalvulina, Trocholina, Valvulinidae and ?Everticyclammina, which are most numerous here, ooids also originate from the platform top (see Gale, 2014). The facies association of distal turbidites, hemipelagic deposits, clast-supported debris breccias, and slumps points to deposition on a slope of the basin (Mullins \& Cook, 1986).

From the $63^{\text {rd }}$ meter onwards, virtually only crinoids and intraclasts constitute the resedimented material, while the strictly platform-top elements are missing. Haas and Tardy-Filács (2004) suggested that the large amount of crinoids within the Rhaetian carbonates originated from terrace-like slopes, since crinoids are not a common element of uppermost Triassic carbonate platforms and reefs. Crinoid-dominated sand-sized material was also interpreted to originate from a shallow pelagic environment by Rožič et al. (2017, with references). In light of this study, this could indicate major changes in the topography of the Julian Carbonate Platform and the establishment of a step-like topography along normal faults.

Ferromanganese enrichments at the contact between the Zatrnik Formation and the overlying Ribnica Breccia point to a reduced sedimentation rate (Šmuc \& Goričan, 2005). The Ribnica Breccia in the Zajamniki section is thinner and finer grained in the Zajamniki section than in the Rib- nica Valley, as was noted in Goričan et al. (2012). In the Ribnica Valley, individual beds reach a thickness of up to $5 \mathrm{~m}$, containing up to $40 \mathrm{~cm}$ large clasts and chert clasts some $1 \mathrm{~m}$ in size. The breccia was interpreted there as debris-flow deposit (Kukoč, 2014; Goričan et al., 2018). Intraclastic-crinoid wackestone and stylolitised intraclastic rudstone, which are part of the microfacies assemblage of the Ribnica Breccia in the Zajamniki section, are also interpreted here as debris-flow deposits (the former due to mud-supported and chaotically distributed clasts, the latter owing to its breccia nature). These mix with possible turbidite deposits (crinoid-intraclastic packstone and rudstone), or gravity-flow deposits of some other type (bioclastic wackestone to packstone). We are unsure how to interpret filament packstone and rudstone - either as autochthonous or allochthonous deposits, but Rožič and Šmuc (2011) recorded identical microfacies types from turbidites within the Perbla Formation of the Slovenian Basin.

\section{Stratigraphic comparisons}

The lack of biostratigraphic data from this and from most of the previously investigated sections mentioned herein does not allow for precise correlations between the sections. However, the successions summarised below follow a similar pattern, suggesting a common cause.

From Mt. Mangart, Šmuc and Goričan (2005) described a stratigraphic succession recording the evolution from the margin of the Julian Carbonate Platform to a deeper basin. The succession starts with Lower Jurassic peloidal and oncoidal limestones, probably deposited in the marginal belt of a shallow-water platform. It then continues with bioclastic limestone rich in echinoderms, ammonites, sponge spicules, and foraminifers Lenticulina, Agerina (here interpreted as small Ophthalmidium), Textulariidae, and Valvulinidae, deposited on a distal shelf, possibly during the Pliensbachian. At the top, this unit contains a few beds of fine-grained breccia and calcarenite, and finally ends with red siliceous limestone impregnated with Fe-Mn. The overlying shale and siliceous limestone contain early Toarcian radiolarian fauna.

Another marginal succession was recorded on Mt. Kobla by Rožič and Šmuc (2009), and Rožič et al. (2014). The lower part of the 150-m-long section is made up of ooidal/peloidal limestone deposited on a carbonate platform. These beds are followed by bioclastic limestone with common sponge spicules and crinoids alternating with 
crinoidal limestone. Ammonites suggest Pliensbachian age (Rožič et al., 2014). Neptunian dykes filled with crinoid debris and a breccia bed some meters thick are present at the top. Above follows a bed of marlstone $50 \mathrm{~cm}$ thick, impregnated with ferromanganese oxides (Rožič \& Šmuc, 2009).

Within the Slovenian Basin, the lowermost Jurassic belongs to the Krikov Formation, followed by the Perbla Formation (Rožič, 2009). The Hettangian-Pliensbachian Krikov Formation in its proximal development in the lower part largely consists of ooidal/peloidal limestone, while its upper part is largely made up of crinoid-rich calciturbidites and is rich in diverse clasts of eroded basinal to slope limestones. The overlying Perbla Formation is Toarcian in age and consists of marlstone and hemipelagic limestone, in the lower part locally impregnated with manganese (Rožič, 2009; Rožič \& Šmuc, 2009).

The shift from the micritic Zatrnik limestone to crinoid-dominated Zatrnik limestone thus seems to be in accordance with previous observations and, although precise dating is missing, probably took place during the Pliensbachian, when the accelerated subsidence changed the paleotopography of the Julian Carbonate Platform.

\section{Conclusions}

The following conclusions follow from the present study:

1) The "Hierlatz facies," as well as the uppermost part of the "classical" Zatrnik Formation, are Early Jurassic in age.

2) The uppermost "classical" Zatrnik Formation consists of distal turbidite deposits, probably hemipelagic deposits, and some debris-flow deposits. Slumping of the sediment is common in the "Hierlatz facies" in the studied section.

3) The shift towards the crinoid-dominated "Hierlatz facies" could be due to changes in the paleotopography of the adjacent platform and its slopes. Comparison to previously recorded successions suggests that the change occurred during the Pliensbachian.

4) The Triassic-Jurassic boundary should be sought a few tens of meters below the "Hierlatz facies" of the Zatrnik Formation. Although sedimentation was largely affected by gravity flows, the facies seems more distal than in the sections of the Slatnik Formation studied so far, thus promising a somewhat more complete record of the Triassic-Jurassic boundary events. Further research will thus be devoted to locating this boundary.

\section{Acknowledgements}

This study was financially supported by the Slovenian Research Agency (Programme No. P1-0011 to L.G.). The technical staff of the Geological Survey of Slovenia is acknowledged for its preparation of thin sections and for processing of the conodont samples.

\section{References}

Bosellini, A., Gianolla, P. \& Stefani, M. 2003: Geology of the Dolomites. Episodes, 26: 181-185.

Breda, A. \& Preto, N. 2011: Anatomy of an upper Triassic continental to marginal-marine system: the mixed siliciclastic-carbonate Travenanzes Formation (Dolomites, Northern Italy). Sedimentology, 58: 1613-1647.

Breda, A., Preto, N., Roghi, G., Furin, S., Meneguolo, R., Ragazzi, E., Fedele, P. \& Gianolla, P. 2009: The Carnian Pluvial Event in the Tofane area (Cortina d'Ampezzo, Dolomites, Italy). Geo. Alp, 6: 80-115.

Budkovič, T. 1978: Stratigrafija Bohinjske doline. Geologija, 21: 239-244.

Buser, S. 1980: Explanatory Book to Basic Geological Map SFRY 1: 100.000, Sheet Celovec. Zvezni geološki zavod, Beograd: $62 \mathrm{p}$.

Buser, S. 1986: Explanatory Book to Basic Geological Map SFRY 1: 100.000, Sheets Tolmin and Videm (Udine). Zvezni geološki zavod, Beograd: $103 \mathrm{p}$.

Buser, S. 1989: Development of the Dinaric and the Julian carbonate platforms and of the intermediate Slovenian Basin (NW Yugoslavia). Mem. Soc. Geol. It., 40: 313-320.

Buser, S. 1996: Geology of Western Slovenia and its paleogeographic evolution. In: Drobne, K., Goričan, Š. \& Kotnik, B. (eds.): International workshop Postojna '96: The role of impact processes and biological evolution of planet Earth. Založba ZRC, Ljubljana: 111-123.

Chiocchini, M., Farinacci, A., Mancinelli, A., Molinari, V. \& Potetti, M. 1994: Biostratigrafia a foraminiferi, dasicladali e calpionelle delle successioni carbonatiche Mesozoiche dell'Appennino Centrale (Italia). Studi Geol. Camerti, spec. iss. 1994: 9-130.

Cousin, M. 1981: Les rapports Alpes-Dinarides. Les confins de l'Italie et de la Yougoslavie. Soc. Géol. Nord, 5: vol I: 1-521, vol. II Annexe: $1-521$.

Diener, C. 1884: Beitrag zur Geologie des Zentralstockes der julischen Alpen. Jb. Kais. König. Geol. R.-A., 34: 659-706. 
Dozet, S. \& Buser, S. 2009: Triassic. In: Pleničar, M., Ogorelec, B. \& Novak, M. (eds.): The Geology of Slovenia. Geološki zavod Slovenije, Ljubljana: 161-214.

Dunham, R.J. 1962: Classification of carbonate rocks according to depositional texture. In: Han, W.E. (ed.): Classification of carbonate rocks, A symposium. American Ass. Petrol. Geol. Mem., Tulsa: 108-121.

Fugagnoli, A., Giannetti, A. \& Rettori, R. 2003: A new foraminiferal genus (Miliolina) from the Early Jurassic of the Southern Alps (Calcari Grigi Formation, Northeastern Italy). Rev. Espan. Micropal., 35: 43-50.

Gale, L. 2014: Lower Jurassic foraminiferal biostratigraphy of Podpeč Limestone (External Dinarides, Slovenia). Geologija, 57/2: 119-146. https://doi.org/10.5474/geologija.2014.011

Gale, L., Celarc, B., Caggiati, M., KolarJurkovšek, T., Jurkovšek, B. \& Gianolla, P. 2015: Paleogeographic significance of Upper Triassic basinal succession of the Tamar Valley, northern Julian Alps (Slovenia). Geol. Carpathica, 66: 269-283. https://doi. org/10.1515/geoca-2015-0025

Gale, L., Kolar-Jurkovšek, T., Karničnik, B., Celarc, B., Goričan, ড̌s. \& Rožič, B. 2019: Triassic deep-water sedimentation in the Bled Basin, eastern Julian Alps, Slovenia. Geologija, 62/2: 153-173. https://doi. org/10.5474/geologija.2019.007

Gianolla, P., Mietto, P., Rigo, M., Roghi, G. \& De Zanche, V. 2010: Carnian-Norian paleogeography in the eastern Southern Alps. Albertiana, 39: 64-65.

Goričan, Š., Košir, A., Rožič, B., Šmuc, A., Gale, L., Kukoč, D., Celarc, B., Črne, A.E., KolarJurkovšek, T., Placer, L. \& Skaberne, D. 2012: Mesozoic deep-water basins of the eastern Southern Alps (NW Slovenia). J. Alp. Geol., 54: 101-143.

Goričan, Š., Žibret, L., Košir, A., Kukoč, D. \& Horvat, A. 2018: Stratigraphic correlation and structural position of Lower Cretaceous flysch-type deposits in the eastern Southern Alps (NW Slovenia). Int. J. Earth Sci., 107: 2933-2953. https://doi.org/10.1007/ s00531-018-1636-4

Haas, J. \& Tardy-Filácz, E. 2004: Facies changes in the Triassic-Jurassic boundary interval in an intraplatform basin succession at Csővár (Transdanubian Range, Hungary). Sed. Geol., 168/1-2: 19-48. https://doi.org/10.1016/j. sedgeo.2004.03.002
Härtel, F. 1920: Stratigraphische und tektonische Notizen über das Wocheiner Juragebiet. Verh. Geol. Staatsanstalt, 8-9: 134-153.

Kolar-Jurkovšek, T., Buser, S. \& Jurkovšek, B. 1983: Zgornjetriasne plasti zahodnega dela Pokljuke. RMZ, 30: 151-185.

Kovács, S., Sudar, M., Grădinaru, E., Gawlick, H.J., Karamata, S., Haas, J., Péro, C., Gaetani, M., Mello, J., Polák, J., Aljinović, D., Ogorelec, B., Kolar-Jurkovšek, T., Jurkovšek, B. \& Buser, S. 2011: Triassic evolution of the tectonostratigraphic units of the Circum-Pannonian Region. Jb. Geol. B.-A., 151: 199-280.

Kukoč, D. 2014: Jurassic and Cretaceous radiolarian stratigraphy of the Bled Basin (northwestern Slovenia) and stratigraphic correlations across the Internal Dinarides (PhD thesis). Faculty of Natural Sciences and Engineering, Ljubljana: 257 p.

Kukoč, D., Goričan, Š. \& Košir, A. 2012: Lower Cretaceous carbonate gravity-flow deposits from the Bohinj area (NW Slovenia): evidence of a lost carbonate platform in the Internal Dinarides. Bull. Soc. Géol. France, 183: 383-392.

Mancinelli, A., Chiocchini, M., Chiocchini, R.A. \& Romano, A. 2005: Biostratigraphy of Upper Triassic-Lower Jurassic carbonate platform sediments of the central-southern Apennines (Italy). Riv. Ital. Paleont. Strat., 111/2: 271283. https://doi.org/10.13130/2039-4942/6314

Mullins, H.T. \& Cook, H.E. 1986: Carbonate apron models: Alternatives to the submarine fan model for paleoenvironmental analysis and hydrocarbon exploration. Sed. Geol., 48: 37-79. https://doi.org/10.1016/0037-0738(86)90080-1

Placer, L. 2008: Principles of the tectonic subdivision of Slovenia. Geologija, 51/2, 205-217. https://doi.org/10.5474/geologija.2008.021

Ramovš, A. 1986: Paläontologisch bewiesene Karn/Nor-Grenze in den Julischen Alpen. Newslett. Strat., 16: 133-138.

Ramovš, A. 1998: Conodonten-Stratigraphie der Obertrias von Slowenien: Ergebnisse eidener Untersuchungen. Geologija, 40: 223-232. https://doi.org/10.5474/geologija.1997.009

Rožič, B. 2009: Perbla and Tolmin formations: revised Toarcian to Tithonian stratigraphy of the Tolmin Basin (NW Slovenia) and regional correlations. Bull. Soc. Géol. France, 180: 411-430.

Rožič, B. \& Šmuc, A. 2009: Jurska evolucija prehodne cone med Julijsko karbonatno platofrmo in Slovenskim bazenom. Geol. Zbornik, 20: $146-151$. 
Rožič, B. \& Šmuc, A. 2011: Gravity-flow deposits in the Toarcian Perbla Formation (Slovenian basin, NW Slovenia). Riv. Ital. Paleont. Strat., 117/2: 283-294. https://doi. org/10.13130/2039-4942/5975

Rožič, B., Venturi, F. \& Šmuc, A. 2014: Ammonites from Mt Kobla (Julian Alps, NW Slovenia) and their significance for precise dating of Pliensbachian tectono-sedimentary event. RMZ, 61: 191-201.

Rožič, B., Kolar-Jurkovšek, T., Žvab Rožič, P. \& Gale, L. 2017: Sedimentary record of subsidence pulse at the Triassic/Jurassic boundary interval in the Slovenian Basin (eastern Southern Alps). Geol. Carpathica, 68/6: 543561. https://doi.org/10.1515/geoca-2017-0036

Rožič, B., Popit, T., Gale, L., Verbovšek, T., Vidmar, I., Dolenec, M. \& Žvab Rožič, P. 2019: Origin of the Jezero v Ledvicah lake; a depression in a gutter-shaped karstic aquifer (Julian Alps, NW Slovenia). Acta Carsologica, 48: 265-282. https://doi.org/10.3986/ac.v48i3.7446
Septfontaine, M. 1988: Towards an evolutionary classification of Jurassic lituolids (foraminifera) in carbonate platform environment. Rev. Paleobiol., spec. vol. 2 (Benthos '86): 229-256.

Šmuc, A. 2005: Jurassic and Cretaceous stratigraphy and sedimentary evolution of the Julian Alps, NW Slovenia. ZRC Publishing, ZRC SAZU, Ljubljana, 98 p.

Šmuc, A. \& Goričan, Š. 2005: Jurassic sedimentary evolution of a carbonate platform into a deep-water basin, Mt. Mangart (Slovenian-Italian border). Riv. Ital. Paleont. Strat.,111/1: 45-70. https://doi.org/10.13130/2039-4942/6269

Šmuc, A. \& Rožič, B. 2010: The Jurassic Prehodavci Formation of the Julian Alps: easternmost outcrops of Rosso Ammonitico in the Southern Alps (NW Slovenia). Swiss J. Geosci., 103/2, 241-255. https://doi. org/10.1007/s00015-010-0015-3

Wright, V.P. 1992: A revised classification of limestones. Sed. Geology, 76: 177-185. 